\title{
Gold-Copper-Zinc Alloys with Shape Memory
}

\author{
G. B. Brook and R. F. Iles \\ Fulmer Research Institute, Stoke Poges, England
}

\begin{abstract}
A limited examination of the shape-memory properties of a range of gold-copper-zinc alloys has shown that shape-memory occurs in a fairly wide range of compositions in which there is flexibility to optimise other important properties such as hot workability, mechanical strength and ductility.
\end{abstract}

The gold-cadmium intermetallic compound, $\mathrm{AuCd}$, has been known to have shape-memory properties for many years; although many patents have been granted for devices making use of the shape-memory properties of this alloy, no commercial use has been possible because the alloy is too brittle. It was not until shape-memory was discovered in the compound $\mathrm{TiNi}$, which is ductile in polycrystalline form, that the industrial use of memory alloys became possible.

The potential for gold memory alloys has been discussed in an earlier article in this journal (1) in which the phenomenon of shape-memory was explained and some examples were illustrated of gold alloys which have shape-memory together with sufficient ductility for them to be fabricated to sheet or wire by conventional methods.

The Chamber of Mines of South Africa has supported a limited feasibility study at Fulmer Research Institute to evaluate a range of compositions in one of the most promising systems, the pseudo-binary system between the ductile copper-zinc memory alloys, the beta brasses, and the less ductile gold-zinc alloys based on AuZn.

The alloys selected contained between 40 and 60 per cent of gold by weight (these are now the subject of world wide patents (2)).

\section{Selection of Alloys}

Previous examination of the beta phase in the system gold-copper-zinc has been very limited, with most work concentrating on the crystallography of a specially ordered type of beta phase known as the "Heusler" alloy. Heusler ordering occurs at approximately $\mathrm{Au}_{25} \mathrm{Cu}_{25} \mathrm{Zn}_{50}$ (where the subscripts refer to atomic percentages), but the beta phase itself forms a continuous single-phase field between the gold-zinc and copper-zinc binary systems.

The temperature at which the memory phenomenon is exhibited is determined by the martensitic transformation of the beta phase. This temperature $M_{s}$ temperature, varies in an unusual manner in this system. In the binary copper-zinc system the $M_{s}$ temperature falls with increasing zinc content but rises with increasing zinc in the gold-zinc system (3). Near the Heusler composition, at constant zinc content, the $M_{s}$ increases to maximum and then falls again $(4,5,6,7,8)$ as copper replaces gold.

The available data on ternary alloys from Fulmer and published data have been assembled in Figure 1, and $M_{s}$ vs. composition contours and ternary beta phase boundaries have been estimated. The beta phase in binary gold-zinc melts at about $640^{\circ} \mathrm{C}$, and in binary copper-zinc at about $920^{\circ} \mathrm{C}$; hence the upper limits to the extent of the beta phase field have been constructed by joining the relevant boundaries at $850^{\circ} \mathrm{C}$ for copper-zinc and $600^{\circ} \mathrm{C}$ for gold-zinc. (The wider boundaries in Figure 1 (upper right) are not isothermal). Compositions near the Heusler alloys, for instance, will melt at some intermediate temperature. Similarly, the ternary beta-phase field at room temperature has been estimated from the behaviour of the parent binary alloys. The supersaturation of a beta phase rapidly quenched from a high temperature can be estimated by the amount by which its composition differs from that of the equilibrium low temperature beta phase. The greater the degree of supersaturation, the less stable the alloy will be on slow cooling from the betaphase field or on heating to temperatures in the region of $200-250^{\circ} \mathrm{C}$.

The experimentally determined $M_{s}$ temperatures are shown in Figure 1 for alloys containing 45, 47 and 49 atomic percentage of zinc. From these points, and the $M_{s}$ temperatures in the binary alloys, contours of constant $M_{s}$ temperature have been estimated. The "ridge" of the maximum $M_{s}$ temperatures is shown by the dotted line near the "Heusler" compositions; actual values of the $M_{s}$ 


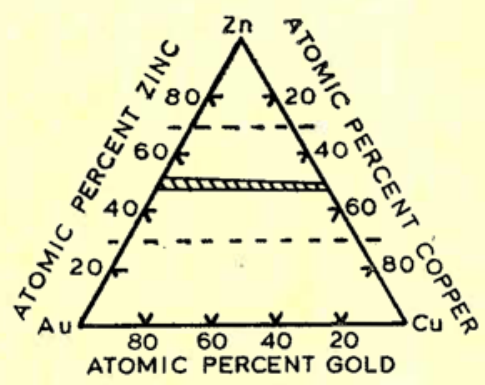

Beta phase field at $20^{\circ} \mathrm{C}$

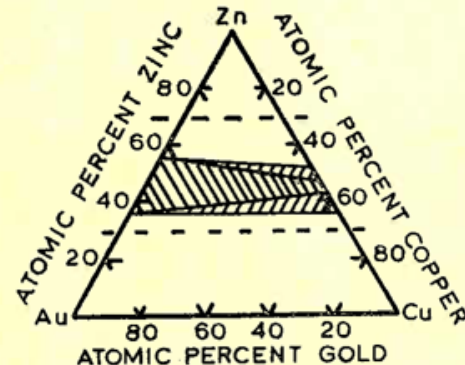

Beta phase field at $850^{\circ} \mathrm{C} \mathrm{CuZn}$ to $600^{\circ} \mathrm{C}$ AuZn (outer boundaries) and $600^{\circ} \mathrm{C}$ isotherm (inner boundaries)

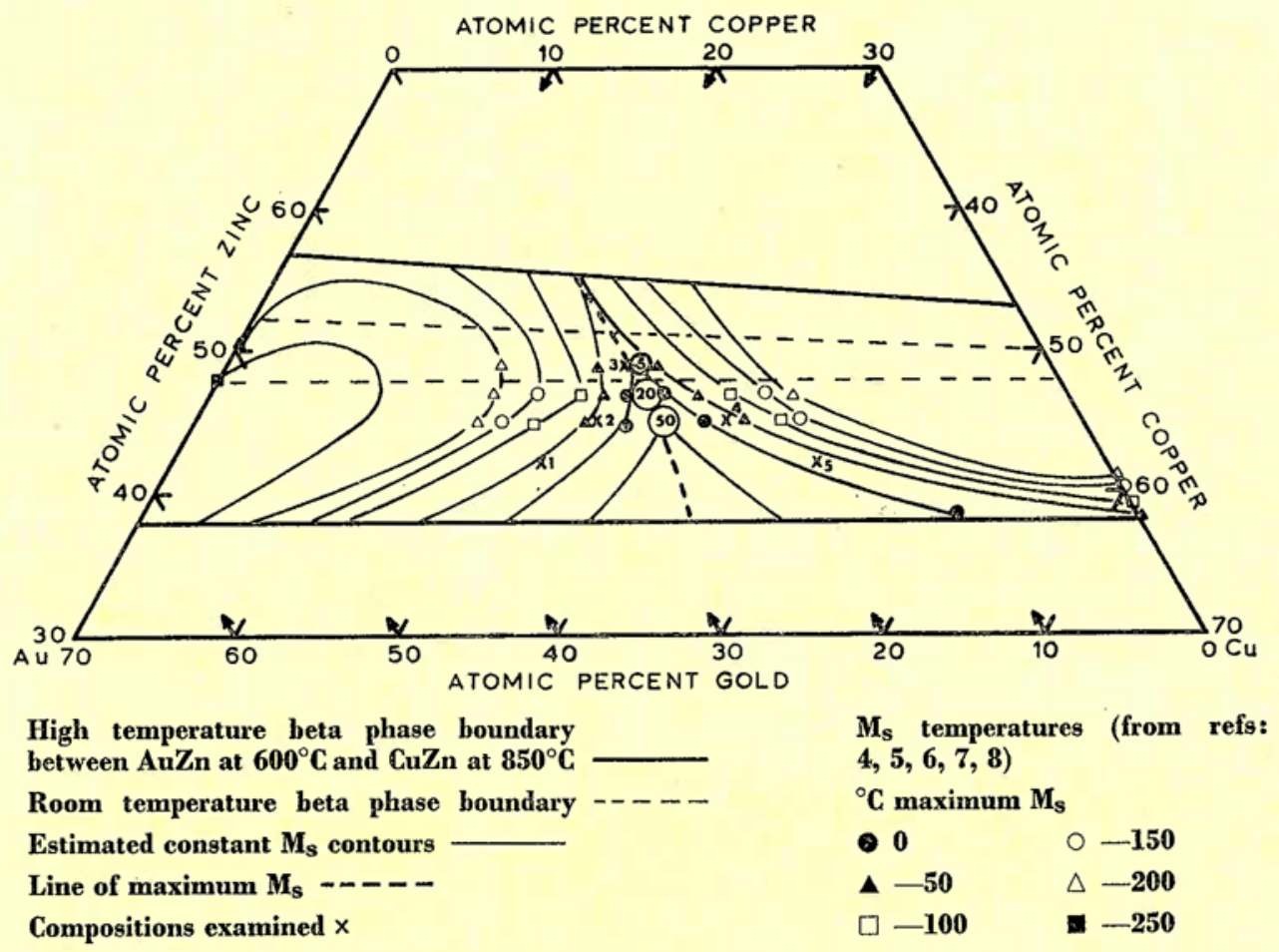

Fig. 1 Section of the gold-copper-zinc ternary phase diagram, showing beta phase field at high temperature (between $\mathrm{AuZn}$ a $600^{\circ} \mathrm{C}$ and $\mathrm{CuZn}$ at $850^{\circ} \mathrm{C}$ ), and contours of constant $\mathrm{M}_{\mathrm{s}}$ temperature estimated from known data

temperatures along this ridge have also been inserted.

The diagram constructed from these very limited data was used to select five compositions with gold contents between approximately 40 and 60 per cent by weight and with predicted $M_{s}$ temperatures of $-30^{\circ} \mathrm{C}$. These alloys are marked by crosses numbered 1 to 5 in Fig. 1. The nominal compositions of the five alloys are shown in Table $I$, together with analysed compositions for the first two alloys. All compositions referred to subsequently are nominal since these lie very close to the actual compositions.

The alloys were prepared from fine gold granules and turnings of high purity zinc and degassed cathode copper. Small melts of total weight $80 \mathrm{~g}$ were produced by encapsulating in evacuated quartz tubes, and melting in an R.F. induction coil. Molten alloys were shaken to ensure thorough mixing. The encapsulated ingots were then homogenised for 3 days at $600^{\circ} \mathrm{C}$.

\section{Examination of the Alloys}

Alloys 1 and 2 were essentially single phase after quenching from $600^{\circ} \mathrm{C}$. (Figures 2 and 3.)

Alloy 3 contained grain boundary films of gamma phase (Figure 4), i.e. it contains excess zinc.

Alloys 5 and 6 contained excess alpha phase when 
Table I

The Range of Au-Cu-Zn Alloys Examined

\begin{tabular}{|c|c|c|c|c|c|c|c|}
\hline \multirow{2}{*}{$\begin{array}{l}\text { Alloy } \\
\text { No. }\end{array}$} & \multicolumn{3}{|c|}{ Weight per cent } & \multicolumn{3}{|c|}{ Atomic per cent } & \\
\hline & $\mathrm{Au}$ & $\mathrm{Cu}$ & $\begin{array}{c}Z n \\
\text { by diff. }\end{array}$ & $\mathrm{Au}$ & $\mathrm{Cu}$ & $\begin{array}{c}\mathrm{Zn} \\
\text { by diff. }\end{array}$ & \\
\hline $\begin{array}{c}\mathrm{ACZ1} \\
\prime \prime\end{array}$ & $\begin{array}{l}62.1 \\
61.6\end{array}$ & $\begin{array}{l}13.2 \\
12.9\end{array}$ & $\begin{array}{l}24.7 \\
25.5\end{array}$ & $\begin{array}{c}35 \\
34.6\end{array}$ & $\begin{array}{l}23 \\
22.4\end{array}$ & $\begin{array}{l}42 \\
43.0\end{array}$ & $\begin{array}{l}\text { nominal } \\
\text { actual }\end{array}$ \\
\hline $\begin{array}{c}\mathrm{ACZ2} \\
\quad "\end{array}$ & $\begin{array}{l}56.6 \\
56.8\end{array}$ & $\begin{array}{l}15.2 \\
15.2\end{array}$ & $\begin{array}{l}28.2 \\
28.0\end{array}$ & $\begin{array}{l}30 \\
30.1\end{array}$ & $\begin{array}{l}25 \\
25.0\end{array}$ & $\begin{array}{l}45 \\
44.9\end{array}$ & $\begin{array}{l}\text { nominal } \\
\text { actual }\end{array}$ \\
\hline $\mathrm{ACZ3}$ & 51.7 & 16.0 & 32.3 & 26 & 25 & 49 & nominal \\
\hline ACZ4 & 46.3 & 22.3 & 31.4 & 22 & 33 & 45 & nominal \\
\hline ACZ5 & 40.2 & 28.7 & 31.1 & 18 & 40 & 42 & nominal \\
\hline
\end{tabular}

quenched from $640^{\circ} \mathrm{C}$ as would be expected from Figure 1. Considering the assumptions made in deriving Figure 1, the alloys had the structures close to those expected.

The workability of the alloys was assessed by forging the ingots of $11.3 \mathrm{~mm}$ diameter at $600^{\circ} \mathrm{C}$ down to $10 \mathrm{~mm}$ diameter followed by hot rolling to $0.8 \mathrm{~mm}$ thick sheet. At each stage, the thickness was reduced by 10 per cent and the alloy then reheated to $600^{\circ} \mathrm{C}$. Alloys 1,4 and 5 could be forged and rolled without difficulty but some cracking occurred in alloys 2 and 3. This is not surprising in view of the presence of the intergranular gamma phase in alloy 3 and shrinkage porosity in alloy 2 .

The $M_{s}$ temperatures of these alloys after quenching from $600^{\circ} \mathrm{C}(1$ and 2$)$ or $640^{\circ} \mathrm{C}(3,4,5)$ were $-100^{\circ} \mathrm{C},-50^{\circ} \mathrm{C},-118^{\circ} \mathrm{C},-64^{\circ} \mathrm{C}$, and below $-196^{\circ} \mathrm{C}$ respectively. These values are reasonably satisfactory considering the assumptions made in deriving Figure 1 and the presence of second phases in alloys 3,4 and 5 which would change the composition of the remaining beta phase and thus the $M_{\mathrm{s}}$ temperature.

All the alloys were paler in colour than pure gold. Alloy 1 had a pale gold colour whereas alloys 2 and 3 were almost white but with a yellow and a pink tinge respectively. Alloys 4 and 5 were like 2 but paler.

Fig. 2 Alloy ACZ2 (57\%Au, 15\% Cu, 28\% $\mathrm{Zn})$ in the cast state. Each grain contains many narrow sub-grains; the fine martensitic structure can be seen within each sub-grain
The metallographic structure of alloy 2 was most unusual. Each grain of the beta phase is subdivided by a series of almost parallel lines (Figure 2). At first sight these resembled micro-cracks but this is unlikely as they were not observed on polished surfaces. Furthermore, on heat-treating at $200^{\circ} \mathrm{C}$, alpha needles precipitated and there was no sign of the parallel lines. Thus the structure is believed to be elongated sub-grains with cell boundaries parallel to certain crystallographic planes. Fine plates of martensite are visible within each sub-grain.

Alloy 1 has the structure of a large-grained beta phase but containing some small precipitates of another phase, possibly alpha. (Figure 3).

The remaining alloys were duplex. In alloy 3 (Figure 4) the second phase had the appearance of the gamma phase, more of which precipitated within the grains. This phase is extremely brittle and some cracks can be seen in Figure 4 propagating within the gamma phase and at its interface with beta.

Alloy 4 was finer in grain size but contained appreciable quantities of the lighter-etching alpha phase. Figure 5 illustrates the alloy after quenching from $640^{\circ} \mathrm{C}$; in the as-cast alloy cooled at a lower rate, more alpha phase was present.

The alloy 5, with least gold, was also an alpha plus beta alloy but the composition of the beta phase was 


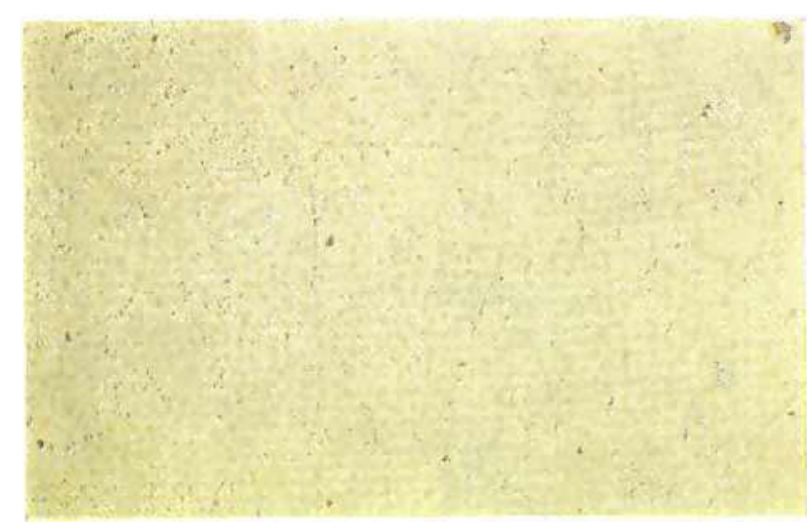

Fig. 3 Alloy ACZ1 (62 \% Au, 13\%Cu, 25\% $\mathrm{Zn}$ ) quenched from $600^{\circ} \mathrm{C}$. Coarse grained beta phase containing fine precipitate, possibly alpha phase

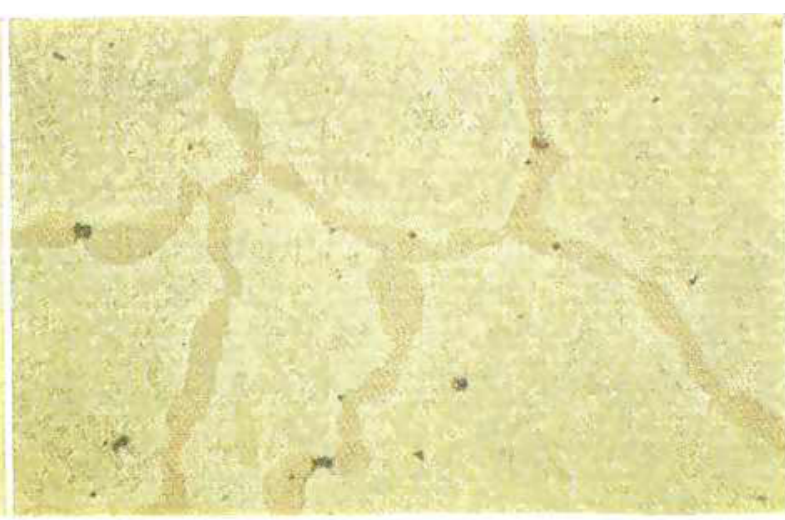

Fig. 4 Alloy ACZ3 (52\%Au, 16\% Cu, 32\%Zn) quenched from $640^{\circ} \mathrm{C}$. Beta phase with precipitation of gamma at grain boundaries and within the grains

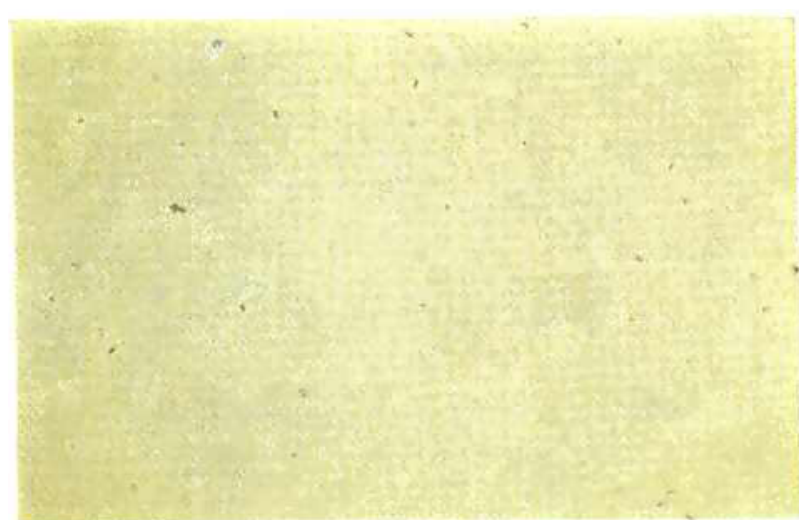

Fig. 5 Alloy ACZ4 (46\%Au, $22 \% \mathrm{Cu}, 32 \% \mathrm{Zn})$ quenched from $640^{\circ} \mathrm{C}$, illustrating a beta phase with alpha phase precipitated at grain boundaries and within grains $\times \mathbf{3 0}$

such that no $M_{s}$ temperature could be detected above $-196^{\circ} \mathrm{C}$ (Figure 6). As it proved impossible to heat-treat this alloy to produce a transformable beta phase, it was not examined further.

A quantitative assessment of ductility and shapememory has been made on the $0.8 \mathrm{~mm}$ sheet produced in the hot workability trials.

Samples of rolled sheet from each alloy were water quenched from $600^{\circ} \mathrm{C}$ (alloys 1 and 2) or $640^{\circ} \mathrm{C}$ (alloys 3 and 4), into water at $20^{\circ} \mathrm{C}$. They were then deformed by bending at room temperature in the beta phase or in liquid nitrogen at $-196^{\circ} \mathrm{C}$, at which temperature beta had transformed to martensite.

Alloys 2 and 3 had virtually no ductility at room temperature. This can be explained from the microstructures; alloy 2 had a large grain size, alloy 3 contained the embrittling grain boundary phase. In both cases a small amount of ductility was observed by bending at $-196^{\circ} \mathrm{C}$. This was probably only about 1 per cent but the original shape was recovered when the specimens were reheated to room temperature. Because both alloys were so brittle it was impossible to make tensile specimens from the sheet.

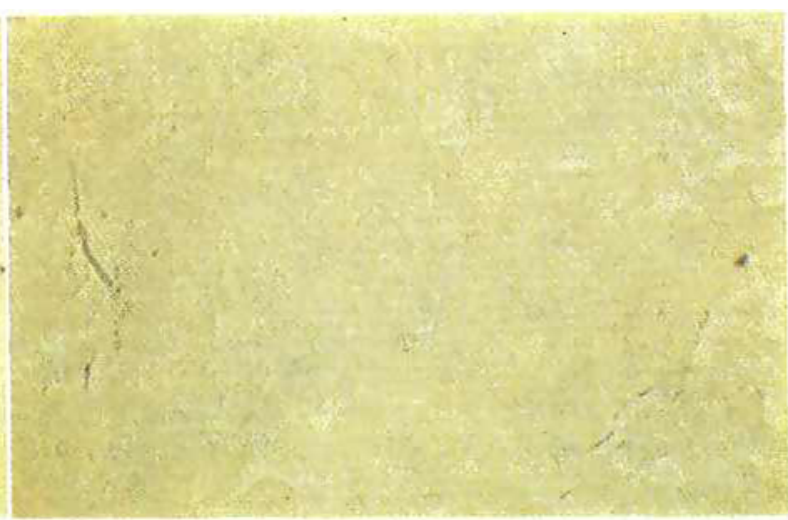

Fig. 6 Alloy ACZ5 (40\%Au, $29 \% \mathrm{Cu}, 31 \% \mathrm{Zn})$ quenched from $640^{\circ} \mathrm{C}$; as ACZ4 but containing more alpha phase

Alloys 1 and 4 possessed far more satisfactory properties. Bend tests at room temperature on alloy 1 indicated a probable ductility of about 2 per cent, and at $-196^{\circ} \mathrm{C}$ about 3 per cent before failure. The recovery of shape on heating was practically complete in the sample deformed at $-196^{\circ} \mathrm{C}$. Alloy 4 had even greater ductility at both room temperature and $-196^{\circ} \mathrm{C}$, although the recovery of shape on heating was not total because of the large amount of nonrecoverable second phase present.

The maximum information from one tensile specimen was obtained by cooling through the $M_{\mathrm{s}}$ temperature after applying at $20^{\circ} \mathrm{C}$ successively larger constant stresses. As the stressed specimen cools under stress, the transformation of beta to martensite causes an elongation to take place, known as "transformation plasticity", which is proportional to the stress applied. When the load is released below the $M_{f}$ and the specimen is reheated, the original dimensions are restored during heating through the $A_{s}$ temperature, because of the shape-memory effect. Hence the test can be used to estimate ductility of the alloy at the $M_{s}$ temperature and 
accurately describes the heat recovery properties. Results of this test for alloys 1 and 4 are shown in Table II below. The strain values are as follows:

$\begin{aligned} 1_{1}= & \text { strain at } 20^{\circ} \mathrm{C} \text { when constant stress } \\ & \text { applited. } \\ 1_{2}= & \text { elongation strain when cooled through } \\ & \text { the } \mathrm{M}_{\mathrm{s}} . \\ 1_{3}= & \text { strain when the stress was unloaded } \\ & \text { below the } \mathrm{M}_{\mathrm{f}} . \\ \mathrm{S} .= & \text { heat recoverable strain when re- }\end{aligned}$ heated.

Eff. per cent $=$ the efficiency of heat recovery $\frac{\text { H.R.S. }}{I_{2}+\left(I_{1}-I_{3}\right)} \times 100$ per cent.

The rise in $M_{s}$ as the constant stress was increased is the usual behaviour in this test. The slight discrepancy between the $M_{s}$ of alloy 1 in Table II and the earlier measurements using electrical potential is a consequence of the greater sensitivity of the electrical method.

The heat-recoverable properties were excellent, especially for alloy 4 considering the large amount of second phase present. The results also indicate that the ductility at the $M_{\mathrm{s}}$ was about 2 per cent for alloy 1 and 3 per cent for alloy 4 . Further specimens of alloy 4 were used for the determination of the stressstrain curve at $20^{\circ} \mathrm{C}$ and $-65^{\circ} \mathrm{C}$ (the $M_{\mathrm{s}}$ temperature), with the results shown in Table III.

The total elongation at the $M_{s}$ temperature was almost 6 per cent, although the specimen failed prematurely in the grips. This also indicates that the specimen of alloy 4 in Table II failed prematurely because previous experience has shown that the maximum elongation achieved on cooling under stress through the $M_{s}$ is slightly greater than with isothermal deformation. It is certain that by adjusting composition and optimising the thermal and mechanical treatment it would be possible to reduce the grain size of alloys 1 and 4 and thus increase toughness.

\section{Summary and Conclusions}

The objective of this limited examination of the shape-memory properties in gold-copper-zinc alloys has been to demonstrate that shape-memory occurs in a wide range of compositions in which there is the flexibility to vary composition to optimise other important properties such as hot workability, mechanical strength and ductility at ambient temperature.

From a prediction of the unknown phase diagram and a rationalisation of the known data on the transformation behaviour of some $\mathrm{Au}-\mathrm{Cu}-\mathrm{Zn}$ alloys, the hypothetical $M_{s}$ composition contours have been estimated in Figure 1. Alloys chosen on this basis have shown this diagram to be roughly true. The errors arise from the fact that the beta phase is more restricted than was estimated.

The uniqueness of this system is that the locus of the maximum $M_{s}$ temperature forms a ridge at roughly equiatomic concentrations of gold and

Table II

(a) Transformation Plasticity and Heat Recovery of Alloy 1

\begin{tabular}{|c|c|c|c|c|c|c|c|}
\hline \multicolumn{2}{|c|}{ Constant Stress } & \multirow{2}{*}{$\stackrel{l_{1}}{\text { per cent }}$} & \multirow{2}{*}{$\begin{array}{c}I_{2} \\
\text { per cent }\end{array}$} & \multirow{2}{*}{$\begin{array}{c}l_{3} \\
\text { per cent }\end{array}$} & \multirow{2}{*}{$\begin{array}{l}\text { H.R.S } \\
\text { per cent }\end{array}$} & \multirow{2}{*}{$\begin{array}{c}\text { Eff. } \\
\text { per cent }\end{array}$} & \multirow{2}{*}{$\begin{array}{l}\mathrm{M}_{\mathrm{s}} \\
{ }^{\circ} \mathrm{C}\end{array}$} \\
\hline $\mathrm{lbf} / \mathrm{in}^{2}$ & $\mathrm{MNm}^{-2}$ & & & & & & \\
\hline 5,000 & 34.5 & 0.05 & 0.20 & 0.05 & 0.20 & 100 & -125 \\
\hline 10,000 & 68.9 & 0.20 & 0.95 & 0.20 & 0.90 & 95 & -118 \\
\hline 12,500 & 86.2 & 0.30 & 1.20 & 0.30 & 1.15 & 96 & -111 \\
\hline 15,000 & 103.4 & 0.40 & 1.60 & 0.35 & 1.55 & 94 & -111 \\
\hline 17,000 & 117.2 & 0.50 & & imen failed & & - & - \\
\hline
\end{tabular}

(b) Transformation Plasticity and Heat Recovery of Alloy 4

\begin{tabular}{|c|c|c|c|c|c|c|c|}
\hline \multicolumn{2}{|c|}{ Constant Stress } & \multirow{2}{*}{$\begin{array}{c}I_{1} \\
\text { per cent }\end{array}$} & \multirow{2}{*}{$\stackrel{I_{2}}{\text { per cent }}$} & \multirow{2}{*}{$\stackrel{I_{3}}{\text { per cent }}$} & \multirow{2}{*}{$\begin{array}{c}\text { H.R.S } \\
\text { per cent }\end{array}$} & \multirow{2}{*}{$\begin{array}{c}\text { Eff. } \\
\text { per cent }\end{array}$} & \multirow{2}{*}{$\underset{{ }^{\circ} \mathrm{C}}{\mathrm{M}_{\mathrm{S}}}$} \\
\hline $\mathrm{lbf} / \mathrm{in}^{2}$ & $\mathrm{MNm}^{-2}$ & & & & & & \\
\hline 6,000 & 41.4 & - & 0.25 & - & 0.25 & 100 & - \\
\hline 11,000 & 75.8 & 0.05 & 1.05 & 0.05 & 1.00 & 95 & -43 \\
\hline 15,000 & 103.4 & 0.30 & 1.35 & 0.25 & 1.40 & 100 & -48 \\
\hline 17,500 & 120.7 & 0.60 & 1.70 & 0.35 & 1.75 & 90 & -29 \\
\hline 22,000 & 151.7 & 0.55 & 2.40 & 0.55 & 2.15 & 90 & -26 \\
\hline 25,000 & 172.4 & 0.65 & \multicolumn{3}{|c|}{ Specimen failed } & - & - \\
\hline
\end{tabular}


Table III

Tensile Tests on Alloy 4

\begin{tabular}{|c|c|c|c|c|c|c|c|}
\hline \multirow{2}{*}{$\begin{array}{l}\text { Temperature } \\
{ }^{\circ} \mathrm{C}\end{array}$} & \multicolumn{2}{|c|}{ Yield Stress } & \multicolumn{2}{|c|}{0.5 per cent Proof Stress } & \multicolumn{2}{|c|}{ U.T.S. } & \multirow{2}{*}{$\begin{array}{c}\text { Total } \\
\text { Elongation } \\
\text { at failure } \\
\text { per cent }\end{array}$} \\
\hline & $\mathrm{Ibf} / \mathrm{in}^{2}$ & $\mathrm{MNm}^{-2}$ & $\mathrm{lbf} / \mathrm{in}^{2}$ & $\mathrm{MNm}^{-2}$ & $\mathrm{lbf} / \mathrm{in}^{2}$ & $\mathrm{MNm}^{-2}$ & \\
\hline 20 & 7,500 & 51.7 & 17,500 & 120.7 & 33,000 & 227.4 & 3.75 \\
\hline-65 & 6,000 & 41.4 & 11,000 & 75.8 & 29,000 & 202.6 & $5.75^{*}$ \\
\hline
\end{tabular}

copper extending in the general direction of increasing zinc content. This means that for a particular $M_{s}$ temperature (which defines the critical temperature below which the alloy has shape memory), there is the choice of a gold or copper-richer alloy.

Alloys 1 and 2 represent two gold-rich alloys. While they both could be satisfactorily hot-worked, the alloy richer in zinc (alloy 2) was brittle at room temperature. Alloy 1 showed some ductility and had a satisfactory shape memory.

Alloy 3, richer in zinc and approximately along the ridge of maximum $M_{s}$ temperature, contained the
Thus this research has shown that commercially useful alloys can be found in the region of 22 atomic per cent $\mathrm{Au}, 33$ atomic per cent $\mathrm{Cu}$ and 45 atomic per cent $\mathrm{Zn}$ ( 46 weight per cent gold, 22 weight per cent copper and 31 weight per cent zinc).

The alloys most stable at $200^{\circ} \mathrm{C}$ were found close to the pseudo-binary single beta phase field and on the gold-rich side of the ridge. It will be necessary to compromise between stability and ductility in the gold alloys depending on the application envisaged.

Table IV summarises the qualitative assessment of the properties of the alloys investigated.

Table IV

Qualitative Assessment of Properties of the Au-Cu-Zn Alloys Examined

\begin{tabular}{c|l|c|c|c}
\hline $\begin{array}{c}\text { Alloy } \\
\text { Number }\end{array}$ & Structure & $\begin{array}{c}\text { Hot } \\
\text { Workability }\end{array}$ & $\begin{array}{c}\text { Ductility at } \\
20^{\circ} \mathrm{C} \text { and } \mathrm{M}_{\mathrm{s}}\end{array}$ & Heat Recovery \\
\hline 1 & single phase beta & fair & fair & good \\
2 & single phase beta & poor & poor & good \\
3 & duplex beta+gamma & poor & poor & good \\
4 & duplex beta+alpha & good & good & good \\
5 & duplex beta+alpha & very good & not examined & not examined
\end{tabular}

brittle gamma phase and was of little interest. Zinc contents as high as 49 atomic per cent are too high to be of commercial interest.

The most attractive alloy was alloy 4 on the copperrich side of the ridge. This actually contained some alpha phase, i.e. a higher zinc content could have been tolerated. The alpha phase did not detract from its shape-memory performance and may well have contributed to the increased ductility. It is worth noting that this contained as much zinc as the brittle alloy 2 , and demonstrates the greater ductility of the alloys on the copper-rich side of the ridge. Alloy 5 was so deficient in zinc that the alpha phase predominated and though very ductile the alloy had no shapememory. All alloys had a pale colour approaching that of white gold.
The best properties were obtained with the essentially single phase beta alloy 1 in the gold-richer alloys, and with the duplex structure of alloy 4 in the copper-richer alloys.

\section{References}

1 G. B. Brook, Gold Bull., 1973, 6, (1), 8-11

2 G. B. Brook and R. F. Iles, British Patent 1,346,047

3 H. Pops and T. B. Massalski, Acta Metall., 1967, 15, (11) $1770-1772$

4 N. Nakanishi, Y. Murakami and S. Kachi, Scripta Metall., 1971, 5, (5), 433-439

5 Y. Murakami, f. Phys, Soc. Fapan, 1972, 33, (5). 13501360

6 Y. Murakami, H. Asano, N. Nakanishi and S. Kachi, Fapan F. Appl. Phys., 1967, 6, (11), 1265-1271

7 N. Nakanishi, Y. Murakami, H. Takehara, Y. Senda, H. Sugiyama and S. Kachi, Fapan F. Appl. Phys., 1968, 7, (3), 302-303

8 N. Nakanishi, Y. Murakami and S. Kachi, Scripta Metall., 1968, 2, (12), 673-675 